\title{
Hard, soft or ambidextrous? Which influence style promotes managers' task performance and the role of political skill*
}

*Accepted for publication in the International Journal of Human Resource Management

\section{Dr ILIAS KAPOUTSIS}

Department of Business Administration, Athens University of Economics and Business, Athens, Greece

\section{Dr ALEXANDROS PAPALEXANDRIS}

Department of Business Administration, Athens University of Economics and Business, Athens, Greece

\section{Dr IOANNIS C. THANOS}

Department of Entrepreneurship, Strategy and Innovation, Lancaster University Management School, Lancaster University, UK

Correspondence to: Dr. Ilias Kapoutsis, Athens University of Economics and Business, School of Business, Department of Business Administration, 76 Patission street, 10434 Athens, Greece. Ph: +30 2108203737. E-mail: ikapoutsis@aueb.gr

Acknowledgements: This research has been co-financed by the European Union (European Social Fund - ESF) and Greek national funds through the Operational Program "Education and Lifelong Learning" of the National Strategic Reference Framework (NSRF) - Research Funding Program: "The impact of the organizational context on human capital development and motivation”. 


\section{Hard, soft or ambidextrous? Which influence style promotes managers' task performance and the role of political skill}

Ambidexterity at the manager level focuses on the crucial, but underexplored, role of managers' knowledge, skills, and behaviors to address competing demands and promote organizational ambidexterity. As such, to successfully complete their assigned duties, managers need to employ the appropriate interpersonal style and calibrate their behavior to different contextual demands. This study highlights the role of the individual in the ambidexterity process by introducing the concept of influence tactic ambidexterity, to denote the frequent use of both hard and soft influence and investigating its role on task performance. Drawing on the literature on ambidexterity and HRM, we analyze data from a sample of 172 middle managers and their corresponding 68 supervisors working for multinational organizations, and provide evidence that influence tactic ambidexterity relates to higher levels and less variation in managers' task performance compared to the sole use of either hard or soft tactics. Our findings also show that political skill positively moderates the relationship between influence tactic ambidexterity and a manager's task performance. Therefore, this study suggests that influence tactic ambidexterity and political skill can be considered valuable HR assets for managers.

Keywords: ambidexterity, influence tactics, task performance, political skill 
The ability of an organization to simultaneously explore new capabilities and exploit more efficiently the existing ones, which is termed organizational ambidexterity, has become increasingly popular (Birkinshaw \& Gupta, 2013; Junni, Sarala, Taras, \& Tarba, 2013; Junni, Sarala, Tarba, Liu, \& Cooper, 2015). In this pursuit to address competing demands, managers’ knowledge, skills, and behaviors are considered essential, yet overlooked, components in making ambidexterity possible (Birkinshaw \& Gupta, 2013; Jasmand, Blazevic, \& de Ruyter, 2012). The HRM field contributes to this direction by focusing on the behavioral view of ambidexterity (Ahammad, Lee, Malul, \& Shoham, 2015; Patel, Messersmith, \& Lepak, 2013) through the adoption of HR practices that encourage employees’ behaviors towards embracing the paradox and balancing conflicting demands for alignment and adaptability. Yet, despite this fervent interest on ambidexterity, little is known about the skills and behaviors that managers need to possess in order to respond to opposing behavioral demands, accomplish their tasks, and help build an ambidextrous organization (Birkinshaw \& Gupta, 2013; Jansen, George, Van den Bosch, \& Volberda, 2008). Further, the role of politics and influence behavior has been largely overlooked in the ambidexterity literature (Junni et al., 2015).

Management of tension and complexity, which are endemic in organizational settings, and crucial in building ambidextrous organizations, requires that managers respond to various roles (Hooijberg, Hunt, \& Dodge, 1997; Lawrence, Lenk, \& Quinn, 2009), equilibrate opposing forces (Lewis, 2000) and tackle conflicting demands (Chang, 2015) by displaying appropriate and diverse modes of influence. Specifically, managers must be capable of promoting both creativity and discipline (Wang \& Rafiq, 2014), by allowing experimentation, while at the same time enforcing tight control (Turner \& Lee-Kelley, 2012), contradictions that have been found to be synergistic in achieving organizational ambidexterity (Andriopoulos \& Lewis, 2009). Hence, in their quest to meet work goals related to 
ambidexterity, managers need to exert diverse and often contradicting (e.g., hard and soft) influence tactics, which are relevant to the situation and responsive to the target's (e.g., their subordinates, peers and supervisors) reactions.

Unlike previous research on ambidexterity, which has mostly focused on the firm or the interfirm level (see Birkinshaw \& Gupta, 2013; Junni et al., 2013 for overviews of these studies), the focus of this study is at the individual level and specifically at the manager level (e.g., Burgess, Strauss, Currie, \& Wood, 2015; Good \& Michel, 2013). Despite the fact that several scholars have long recognized the pivotal role of individuals in shaping ambidexterity in organizations (e.g., Havermans, Den Hartog, Keegan, \& Uhl-Bien, 2015; Jasmand et al., 2012), even today, there is a relative shortage of ambidexterity studies at the individual level (Stokes et al., 2015; Turner, Swart, \& Maylor, 2013; Xing, Liu, Tarba, \& Wood, in press). In this study, we draw on the theoretical underpinnings of ambidexterity from an HRM perspective (e.g., Xing et al., in press) and introduce the concept of influence tactic ambidexterity as a potential determinant for achieving higher and more stable task performance.

We define influence tactic ambidexterity as the frequent use of both hard and soft influence tactics, which can be considered as antipodal and often contradicting behaviors in a manager's influence tactic repertoire. We argue that ambidextrous agents can enjoy the benefits that stem from soft influence tactics (e.g., motivation, engagement, risk taking, and trust) while maintaining efficiency and control through hard influence tactics and, as such, exhibit higher task performance. In addition, to fully capitalize upon these benefits, managers must possess the savvy to effectively understand others in the workplace and adjust their behaviors accordingly. This social competency, delineated as political skill, designates, at large, the extent of success of an influence attempt, as well as its frequency and intensity of use (Kolodinsky, Treadway, \& Ferris, 2007). In other words, managers must combine social 
astuteness with a capacity to demonstrate situationally appropriate behavior under different demands and contexts to effectively achieve their personal and/or organizational goals (Ferris et al., 2005).

Drawing on a sample of middle managers working for Greek multinational corporations, we provide support for a positive relationship between a managers’ influence tactic ambidexterity and their supervisor-rated task performance. In addition, managers who exhibit influence tactic ambidexterity enjoy less variation in their task performance when compared to those who rely solely on soft or hard tactics. We also extend the existing research to empirically demonstrate that political skill can act as a positive moderator on the aforementioned relationship. The above findings have non-trivial implications for HR practices in multinational corporations, which are explored in the discussion section of the paper. In doing so, our study aims to complement a small, but growing, line of research on ambidexterity and HR practices and systems (e.g., Ahammad et al., 2015; Ketkar \& Sett, 2009; Meglio, King, \& Risberg, 2015; Prieto-Pastor \& Martin-Perez, 2015; Xing et al., in press) by shedding more light on the micro-foundations aspects of ambidexterity (Junni et al., 2015).

\section{Theory and Hypotheses}

\section{The Need for Managers to be Ambidextrous in their Behavior}

Lewis and Dehler (2000) ascertain that many leadership theories emphasize the simultaneous presence of contradictions, taking the form of mixed messages, conflicting demands, or opposing views. Such contextual paradoxes which represent important behaviors in developing organizational ambidexterity (Stokes et al., 2015), must be mirrored in managers’ behavior (Lewis, 2000). For example, Good and Michel (2013) argue that individuals must possess the ability to align with contextual demands and display individual ambidexterity, which plays a key role in fostering firm and unit level ambidexterity. Therefore, managers 
need to be behaviorally complex (Hart \& Quinn, 1993) to foster stability and control, while providing inspiration and instilling commitment (Lawrence et al., 2009).

Such complex purposive behaviors can be manifested by the interplay of hard and soft tactics, which reflect polar opposites in managers' behavioral continuum (Sparrowe, Soetjipto, \& Kraimer, 2006). The use of influence tactics can result in both beneficial and disruptive performance outcomes, depending on the context in which they are applied. Exerting pressure and seeking compliance in a direct, assertive manner can trigger feelings of dislike. Nevertheless, an authoritarian management style, which usually involves the use of hard influence tactics, has been found to foster the development of organizational capabilities and can facilitate exploitation learning (Dixon, Meyer, \& Day, 2007), while at the same time can help attain a minimum level of performance, which may not be possible through the use of soft tactics alone. Under certain conditions, relational considerations may require the use of harder tactics to ensure that the target of the influence behavior adequately completes the assigned duties, to communicate dissatisfaction, or to boost performance over a short period of time (Van Knippenberg, Van Knippenberg, Blaauw, \& Vermunt, 1999b). For example, a tight project deadline may compel a manager to shift pressure to group members. Managers may also use hard tactics to address negative or counterproductive behaviors or to ensure fair treatment among group members (Sparrowe et al., 2006). In an experimental study, De Cremer and Van Hiel (2010) showed that unfair treatments on one individual can result in perceived injustice to another which may cause negative reactions, as such, the use of hard tactics to right injustices can send out a strong signal to all group members concerning the leader's tendency to be fair and trustworthy (Dirks \& Ferrin, 2002). In particular, as the Group Engagement Model implies (Tyler \& Blader, 2003), managers may need to exhibit hard tactics to exemplify fair treatment to the other members of the group, which instils 
feelings of trust and respect in the leaders' actions, what is often a necessary requirement for enhancing group membership and coherence (Sparrowe et al., 2006).

\section{The Effects of Hard and Soft Influence Tactics on Performance}

Organizations today need to be efficient in meeting current demands, while also being adaptive and flexible to unpredictable changes in the environment (Tushman \& O’Reilly III, 1996). The role of managers in resolving tensions related to such opposing and incompatible organizational goals is critical (Mom, Van Den Bosch, \& Volberda, 2007; Yoon \& Chae, 2012). In order for managers to consistently meet task objectives, they need to assume multiple roles, effectively tackle contradictory tasks and achieve short and a long term goals that stem from their job description (Smith \& Tushman, 2005). The management of different people, through the exertion of the appropriate influence behavior, lies at the center of a manager's task objectives and is of key importance in achieving task related goals (Patel et al., 2013) and organizational ambidexterity (Jansen et al., 2008). Through their influence behavior, managers need to create an organizational context that is supportive, thereby nurturing organizational learning and stimulating employees’ behavioral ambidexterity (Prieto-Pastor \& Martin-Perez, 2015).

Influence tactics are used by managers to inspire trust and commitment and to ensure that the targets of this influence behavior will carry out specific tasks. These tactics range from friendly attempts to compliment and inspire the target, such as ingratiation, to tactics such as assertiveness that are used to maintain coherence and to pinpoint deviant behaviors of specific group members (Kolodinsky et al., 2007). While tactics differ in nature, they also share many similarities with respect to their purpose, scope, desirability, and strength.

Capitalizing on these similarities, researchers highlighted the usefulness of further classifying proactive influence tactics into broader higher-order categories (Van Knippenberg et al., 1999b). Following the work of Kipnis and Schmidt (1988), van Knippenberg and her 
colleagues (2003; 1999a) advocated categorizing the proactive influence tactics into hard and soft. This categorization is based on their place in the strength dimension - the extent to which the use of a specific influence tactic results in control over the situation and the target (Tepper, Brown, \& Hunt, 1993). In negotiations, for example, hard tactics may be preferred when actors need to meet specific deadlines or satisfy customers' specifications, while soft tactics may try to tap into their counterparts' mind as a subtle way to reduce resistance to change (Jonason, Slomski, \& Partyka, 2012). Thus, tactic strength, which expresses this latitude, can be used to distinguish between hard and soft tactics.

Soft tactics (e.g., ingratiation and reason) aim at the subordinate's affective side, while hard tactics (e.g., assertiveness and upward appeals) aim at the cognitive side. Soft tactics involve polite and friendly behaviors that allow the target the option of whether or not to comply (Barry \& Shapiro, 1992). On the opposite end of the strength dimension, hard tactics consist of actions that are relatively controlling, direct, and coercive, whose main objective is to ensure the target's compliance or communicate the agent's dissatisfaction (Van Knippenberg et al., 1999b). Specifically, a participatory management style that utilizes soft influence tactics can increase the target's positive feelings, arouse enthusiasm, and thereby enhance the likelihood of carrying out a specific request (Liden \& Mitchell, 1988). Moreover, a management style that employs such tactics can foster strategic flexibility, risk-taking, and experimentation and innovation and thereby foster a climate for exploration learning (Dixon et al., 2007). Soft tactics are considered to be more socially desirable, and they contribute to the maintenance of the agent-target relationship. On the other hand, hard tactics involve the use of power to increase an agent's responsibility, accountability, and professionalism. As such, they can increase others' compliance and help sway them to perform as expected. Nonetheless, the use of hard tactics is usually perceived as more hostile by targets (Van 
Knippenberg \& Steensma, 2003) since it relies on fear (Berson \& Sosik, 2007) and, thus, can place a strain on the agent-target relationship.

\section{Influence Tactic Ambidexterity and Managers’ Task Performance}

While the frequent use of both soft and hard influence tactics is compelling, there is scarce evidence concerning how their combination affects different facets of performance. For instance, Kipnis and Schmidt (1988) observed that managers who frequently used seven upward influence strategies (i.e., shotgun style) received less favorable performance evaluations and salaries than tacticians (i.e., managers who relied heavily upon reason and who had at least average scores for the other strategies) or bystanders, who exhibited infrequent use of all seven influence strategies. Similarly, studies by Case, Dosier, Murkison, and Keys (1988), and Dosier, Case, and Keys (1988) found that combined tactics could be more effective than the use of a single tactic. Furthermore, Falbe and Yukl (1992) showed that combining hard and soft tactics could provide balanced results in terms of resistance, compliance, and commitment. Finally, Van de Vliert, Nauta, Giebles, and Janssen (1999) presented empirical evidence that the combination of two apparently different conflict behaviors (i.e., problem solving and forcing) was more effective than the use of either behavior in isolation. Consequently, we assert that the frequent use of both hard and soft tactics, which we term influence tactic ambidexterity, can enable managers to capitalize upon benefits stemming from their use. This is in line with the theoretical premise drawn from the negotiation literature which suggests that managers must simultaneously focus on tasks and relationships (Blake \& Mouton, 1964), or as principled negotiation dictates, be hard on the problem and soft on the people (Fisher, Ury, \& Patton, 2011) by displaying both assertiveness and empathy (Mnookin, Peppet, \& Tulumello, 1996).

Organizational ambidexterity addresses the need for managing trade-offs between conflicting organizational demands by focusing on exploration-exploitation, efficiency- 
flexibility, and alignment-adaptability (Simsek, 2009). The bulk of available empirical work on organizational ambidexterity has been carried out at the firm or business unit level and there is a relative shortage of studies at the individual level (Junni et al., 2013; Turner et al., 2013). Previous studies on organizational ambidexterity have been mostly concerned with identifying its antecedents (e.g., Cegarra-Navarro \& Dewhurst, 2007; Heavey, Simsek, \& Fox, 2015) or its consequences for unit (e.g., Kostopoulos, Bozionelos, \& Syrigos, 2015) or firm performance (e.g., Cao, Gedajlovic, \& Zhan, 2009). Ambidexterity is shaped by an array of factors related to the structure (e.g., Jansen, Van den Bosch, \& Volberda, 2006), leadership characteristics (e.g., Havermans et al., 2015) and broader context (e.g., Gibson \& Birkinshaw, 2004). Moreover, although previous studies have used an array of different measures of ambidexterity, outcomes, levels of analysis and samples, there is concrete evidence that the pursuit of ambidexterity is positively related to firm performance, especially in dynamic or turbulent settings (Cegarra-Navarro \& Dewhurst, 2007; O'Reilly \& Tushman, 2013).

The context in which ambidexterity is used in this study departs from the traditional perspective described above. In our research, the concept of ambidexterity is used to reflect the frequent use of seemingly incompatible behavioral styles to achieve personal and organizational goals. Specifically, we argue that managers need to display antipodal influence behavior (i.e., frequent use of soft and hard tactics) to consistently achieve a high level of performance. This assertion is in line with the qualitative findings of Havermans et al. (2015) who posit that, to help implement ambidexterity, managers need to employ leadership practices (e.g., stimulating discussions, being accepting to mistakes, and involving others) that enable exploration while also enforcing rules and redirecting effort to fit management expectations that enable exploitation. Therefore, a manager who uses soft tactics could harvest the benefits associated with transformational leadership, while the use of hard tactics could surpass the pitfalls of inertia and functional myopia. 
Hypothesis 1: Managers' influence tactic ambidexterity will positively relate to their task performance.

Hard tactics involve the use of coercive power and, as such, they usually put a strain in the agent-target relationship (Bruins, 1999). Still, many managers resort to the use of hard tactics as a "drastic medicine” for situations where compliance or exemplification is needed. Reliance on hard tactics may increase a target's likelihood of carrying out a specific request, but requires a sound justification and rationale to prevent undermining the agent-target relationship. For example, confronting others face to face, placing strict deadlines, or demanding compliance may be perceived as overly strict, or dissonant. Relying exclusively on hard tactics could be perceived as an abusive behavior that diminishes interpersonal justice and triggers strong negative emotions or even deviant behavior (Rafferty \& Restubog, 2011). As such, hard tactics may occasionally enhance performance, but could also lead to demotivation and resistance (Van Knippenberg \& Steensma, 2003), which has been associated with negative organizational outcomes (Kirkman \& Shapiro, 1997).

On the other hand, when a manager engages in prosocial behavior, the target of this influence behavior will be inclined to reciprocate this sentiment to maintain a positive balance of sentiments in the relationship (Kolodinsky et al., 2007). As such, managers are inclined to employ soft influence tactics in the majority of their task requests to maintain the agent-target relationship and increase motivation and commitment (Falbe \& Yukl, 1992). Nevertheless, being overly friendly and giving increased leeway can sometimes lead to inertia, due to social loafing, and can result in low performance.

Building on the disparate outcomes of these two influence behaviors, we argue that managers that display influence tactic ambidexterity may reap benefits related to both influence tactic categories, whilst avoiding certain of their shortcomings. Specifically, ambidextrous agents could foster a supportive climate that enhances motivation, instills trust 
and respect. Such a climate would promote fair treatment by rewarding good performance and would signal to all parties that inertia and social loafing will not be tolerated. Therefore, ambidextrous agents are expected to exhibit the lowest variation in their task performance compared to those that rely solely on soft or hard tactics.

Hypothesis 2: Managers displaying influence tactic ambidexterity will exhibit less intragroup variation in their task performance compared to managers that mostly rely on the use of either hard or soft tactics.

\section{Political Skill as a Quality Assurance Mechanism}

Moving beyond the direct effect of influence tactic ambidexterity on task performance, we contend that a relevant social skill may empower this ability to balance among diverse influence modes, by conveying meanings and shaping behaviors depending on the target or situation. Pfeffer (1981) and Mintzberg (1983) were among the first who used the term political skill to describe the competency for successful social influence in various work settings.

Political skill reflects an interpersonal style that helps calibrate behaviors to different contextual demands by employing a manner that is genuine and sincere, which inspires confidence and trust, and results in effective influence over others at work (Ferris et al., 2005; Ferris et al., 2007). It comprises four underlying dimensions (i.e., social astuteness, networking ability, interpersonal influence and apparent sincerity), with each describing a unique capability, that altogether work to ensure the attainment of personal and organizational goals, without seeming manipulative and coercive, even within ambiguous work settings (Ferris et al., 2005; Harris, Maher, \& Ferris, 2016). Social astuteness reflects the ability to map the terrain by noticing contextual cues along with the needs and aspirations of others, which are necessary in the selection of the appropriate mode of influence (e.g., soft versus hard). In addition, through their networking ability, politically skilled managers are more adept at mobilizing others to support their cause or at getting things done (e.g., Fang, Chi, 
Chen, \& Baron, 2015). Those who possess political skill also have the ability to communicate effectively and adjust their actions to contextual demands (i.e., interpersonal influence). Finally, through apparent sincerity, they are able to mask the exertion of soft and hard power in ways that unlock the full potential of each influence mode by securing benevolence and trustworthiness. These four dimensions together may help actors to adopt any behavioral, affective, and cognitive manifestation and hence increase their effectiveness (Ferris et al., 2007; Harris et al., 2016).

From what we know so far, political skill represents a quality assurance mechanism that may affect the outcomes of leadership behavior (Kapoutsis, 2016). Such an assertion is supported by amassing empirical evidence associating political skill with favorable personal and organizational outcomes (e.g., Bing, Davison, Minor, Novicevic, \& Frink, 2011; Ferris, Treadway, Brouer, \& Munyon, 2012; Kimura, 2015; Munyon, Summers, Thompson, \& Ferris, 2015; Wihler, Frieder, Blickle, Oerder, \& Schütte, 2016). For example a meta-analysis by Bing et al. (2011) showed that a positive relationship between political skill and task performance was present, however, such a relationship applied only to occupations that required intense social influence tactics, based on the categorization of Occupational Information Network (O*NET) developed by the U.S. Department of Labor. Munyon et al. (2015) further explain that such positive bivariate associations may be attributed to the fact that those who possess political skill have good chances of building a strong personal reputation. In a similar fashion, recent research (Epitropaki et al., in press; Xing et al., in press) highlights the usefulness of political skill for building high quality relationships by seeking information to process in order to transmit back effective verbal and non-verbal behavioral patterns, which constitutes a valuable asset for ambidextrous managers.

Recently, the political skill literature has expanded its radius by showing that it affects not only personal work outcomes and evaluations, but also group and organization processes 
(Ferris, Perrewé, Daniels, Lawong, \& Holmes, in press). For example, Lvina, Johns, and Vandenberghe (in press) found that team political skill may enhance team cohesiveness and, in turn, team objective performance. Furthermore, Baron, Lux, Adams, and Lamont (2012) suggested that political skill may prove to be a critical resource for mitigating the social cost from engaging corporate political activity to sustain competitive advantage.

\section{The Moderating Role of Political Skill}

With regard to the influence tactic ambidexterity - task performance relationship, ambidextrous managers vested with political skill seem capable of maintaining a sense of self-confidence and control, which instils feelings of comfort in others and contributes to positive affective reactions and trust (Ferris et al., 2007). Furthermore, they can mask the sometimes biased perception of others about the self-serving character of influence tactics (Higgins, Judge, \& Ferris, 2003; Kolodinsky et al., 2007).

Politically skilled managers are adept at adjusting their behavior to different demands and contexts and can deliver the influence attempt in properly calibrated ways in order to successfully interact with and influence others to attain favorable evaluations. (Ferris et al., 2005; Kapoutsis, Papalexandris, Nikolopoulos, Hochwarter, \& Ferris, 2011). Thus, politically skilled managers have the savvy to make better decisions concerning which influence tactics to employ in particular situations and can effectively deploy such tactics in any given context, with the desired outcomes (Ferris et al., 2007; Higgins et al., 2003). In this respect, political skill helps diagnose those influence tactics that seem relevant to the situation and to the target, while it promotes the self-confidence of the agent in exerting influence and increases the effectiveness of influence attempts (Farmer \& Maslyn, 1999; Kolodinsky et al., 2007). Indeed Kimura (2015) suggests that politically skilled employees may fit their behavior to the situation and do so in an authentic manner that reinforces trust, while Wihler et al. (2016) note that leaders who are strong in political skill engage in situationally specific behavior (i.e., 
transformational/relational-oriented or transactional/maintenance-oriented) depending on the needs of multiple stakeholders. Finally, those high on political skill may neutralize stressors (e.g., Perrewé et al., 2004) and help resolve tensions ensued from the use of seemingly antipodal behaviors. Therefore, it is reasonable to expect that complementing influence tactic ambidexterity with political skill can help increase managers’ task performance.

Antithetically, ambidextrous managers low on political skill may use both soft and hard tactics, but without the savvy to adjust these tactics to the situational demands. This way, although they are capable of displaying influence tactic ambidexterity, they may find it difficult to resolve tensions created from the use of these two diverse modes of influence. Besides, the use of an unfitting to the situation influence style may result in counterproductive conflicts, lack of motivation, damaged reputation, and distraction from the actual work. Therefore, the lack of political skill may hamper the positive effect on performance ratings stemming from influence tactic ambidexterity.

Hypothesis 3: Political skill positively moderates the effects of managers' influence tactic ambidexterity on their task performance such that the positive relationship between influence tactic ambidexterity and task performance is stronger for managers with high levels of political skill.

\section{Methods}

\section{Sample and Procedure}

We used data collected via electronic questionnaires from full-time employees of private multinational corporations with more than 250 employees, operating in Greece that represented a broad cross-section of industries. First, we contacted the HR managers of 200 companies, explaining the purpose of the study, the data collection procedure, and the handling of confidential information. Reasons for not participating in this research were mainly due to internal policy restrictions that did not allow external measurement of 
performance and strict policy procedures involving authorization from abroad (multinationals' headquarters). For each of the 28 companies (14\% response rate) that agreed to participate in the study, we requested names and email addresses of randomly selected employees holding a managerial position and permission to contact them for this research. The response rate in this study is comparable to that reported in previous ambidexterity and HR studies (e.g., Wang \& Rafiq, 2014; Yoon \& Chae, 2012).

A total of 278 invites were emailed to managers and 76 to their corresponding supervisors. Managers received an email including a unique link to an online survey. Next, their supervisors received an email with unique links for every manager (their subordinate) that they had to evaluate and a second one to record their demographics. This procedure allowed the matching of manager-supervisor data, while it mitigated risks of systematic responses due to confidentiality breaches. After a maximum of 3 reminders (with a one weak time-lag), we received data from 211 managers and 71 supervisors, indicating a response rate of $75.9 \%$ and $93.4 \%$, respectively. The high response rate was expected since their corresponding companies had provided official authorization.

After removing surveys with no matching supervisor data, we were able to match 172 manager and supervisor dyads representing 68 work groups (response rate of $81.5 \%$ and 95.8\%, respectively). Forty-seven percent of the managers were female, they had 37.8 years of age on average and an average of 7 years of tenure in their current organization. The sixtynine supervisors were $33.8 \%$ female, their average age was 42.93 years, the average organizational tenure was 10.67 years, and the average job tenure was 6.4 years.

Surveys were prepared in English and then translated into Greek following Brislin, Lonner and Thorndike’s (1973) recommended back-translation procedure which has been widely followed in previous Human Resources survey studies (e.g., Birtch, Chiangb, \& Van 
Esch, in press). We conducted a pilot test with academics and practitioners to increase the clarity of the questionnaires.

\section{Measures}

All constructs were measured using well-known multi-item scales and the mean scores were calculated across the items. We present in the following paragraphs the sources from which they were drawn, sample items and their reliability levels. As shown below, the alpha coefficients for all multi-item scales range between 0.72 and 0.90 , indicating high levels of internal reliability.

Task performance. Supervisors rated the task performance of each manager using Williams’s and Anderson’s (1991) seven items performance scale on a 7-point scoring format ranging from strongly disagree (1) to strongly agree (7). Sample items include "this employee adequately completes assigned duties" and "this employee fulfils responsibilities specified in job description". The measure exhibited high internal reliability $(\alpha=.90)$.

Hard and soft influence tactics. We measured the frequency of use of hard and soft influence tactics by managers using items from the Schriesheim and Hinkin (1990) 18-item refinement of the Kipnis, Schmidt, and Wilkinson (1980) measure. To assess hard tactics we used 4 items from the assertiveness and upward appeals subscales. These items were: "Expressed my anger verbally in order to influence the target”, "used a forceful manner to back up request trying such as demands, setting of deadlines and the expression of strong emotion", "had a showdown in which I confronted someone face to face”, and "I relied on the chain of command-on people higher up in the organization who have power over the target”. For soft tactics we used all six items from the ingratiation and reason subscales. Sample items include "Acted in a friendly manner prior to asking for what I wanted" and "explained the reason of my request”. Although the influence tactics taxonomy comprises of more categories, we only selected four (i.e., two for hard and two for soft), as they are considered antipodal behaviors that fall into the opposite polars of the strength dimension (Tepper et al., 
1993; Yukl, Seifert, \& Chavez, 2008). Managers answered each question using a 7-point Likert scale ranging from 1 (I can't remember me ever using this tactic) to 7 (I use this tactic very often), depending on the frequency with which they use these tactics to influence others to carry out requests. The reliability estimates for hard and soft influence tactics were .72 and .81 , respectively.

Influence Tactic Ambidexterity. We operationalized influence tactic ambidexterity by multiplying hard and soft influence tactics, following the recommendation of He and Wong (2004) as well as Cao et al. (2009), since these two categories are argued to complement and augment task performance. In this respect, we mean centered both hard and soft influence tactics variables prior to their multiplication to mitigate the risks of potential multicollinearity in our analyses.

Political skill. The political skill of managers was assessed using the 18-item Political Skill Inventory (PSI) developed by Ferris et al. (2005). Representative items include "I find it easy to develop good rapport with most people” and "I am able to make most people feel comfortable and at ease around me”. A seven-point scoring format was used ranging from strongly disagree (1) to strongly agree (7). The reliability estimate for the scale was .90.

Control variables. We controlled for possible alternative explanations by including gender, age, and organizational tenure as control variables at both level 1 (manager) and level 2 (supervisor).

\section{Consideration of various types of biases and validity test}

We adopted various remedies to minimize the existence of several types of biases associated with survey research which could threaten the validity of our conclusions (Ahammad, Tarba, Liu, Glaister, \& Cooper, 2016). First, to deal with common method bias (Chang, van Witteloostuijn, \& Eden, 2010), we collected data for the dependent and the independent variables from different sources. In particular, the independent (i.e., hard and soft tactics) and 
moderating (i.e., political skill) variables were assessed from the managers, while the dependent variable (i.e., task performance) was assessed from the manager's supervisor.

Second, to examine the possibility of bias resulting from late-response or nonresponse, we compared early (first wave of questionnaires) with late respondents (third wave of questionnaires) on all variables. Next, we assessed whether responding and non-responding firms differ in terms of their size (approximated by their total number of employees). In all cases, t-tests were insignificant, suggesting that late response and non-response was not an issue of concern in this study.

Third, we motivated the respondents to give us accurate responses by providing assurances that their responses would be treated with confidentiality, by making explicit that there were no right or wrong answers and by offering them a summary of the main results of the study (for a similar approach see Ahammad et al., 2016).

Fourth, to ensure proper levels of discriminant validity, we conducted confirmatory factor analyses of our key individual variables (i.e., hard tactics, soft tactics, political skill, and task performance). We estimated a four-factor measurement model with one factor representing each latent variable of the scale. To represent the latent variables of the present study we used both multiple and single indicators, following Jöreskog and Sörbom (1996). Single indicators were created by averaging items for each subscale (for political skill, soft and hard influence tactics). Fit indices showed that the four-factor model had adequate fit, $\chi^{2}$ $(84)=172.98, p<.01$, CFI $=.92$, TLI $=.90$, RMSEA $=.08$, SRMR $=.07$. To further explore the discriminant validity of the scales, we compared the four-factor model to a series of models that each had constrained the correlation of one pair of constructs to 1.00. All chisquare differences were significant at the .01 level, indicating high discriminant validity among constructs (Anderson \& Gerbing, 1988). 


\section{Analytic strategy}

To test hypotheses 1 and 3, and in order to account for the nonlinear dependence in our data due to the fact that participants were nested within supervisors we used hierarchical linear modeling (HLM; Raudenbush, Bryk, Cheong, \& Congdon, 2004) and ran a series of HLM analyses. We used full maximum likelihood estimation so that we could conduct deviance tests to assess improvement in model fit that resulted from the addition of hypothesized predictors (Raudenbush \& Bryk, 2002). Deviance tests are similar to examining differences in $\mathrm{R}^{2}$ values in OLS regression or chi-square differences in SEM and can be used as a method of expressing effect size in multilevel modeling. The substantive interest in this study is the level 1 association between influence tactic ambidexterity and managers' task performance as well as the interaction of ambidexterity and political skill on managers' task performance. Thus, following the recommendations of Enders and Tofighi (2007), we group mean centered all level 1 variables and grand mean centered level 2 controls.

To test hypothesis 2, we first performed a test of homogeneity of variance to assess whether the no emphasis, soft tactics, hard tactics, and influence tactic ambidexterity groups that were formed exhibit equal variances. Then, in order to assess the variation in managers' task performance for each group, we computed the coefficient of variance, which is also termed relative standard deviation, by dividing the standard deviation by the mean for each group (Harrison \& Klein, 2007; He \& Wong, 2004).

\section{Results}

\section{Hierarchical Linear Model Analysis}

As described in the analytic strategy, hypotheses 1 and 3 were tested using HLM. Table 1 presents descriptive statistics and correlations for all study variables.

$$
\text { *** Insert Table } 1 \text { about here *** }
$$


We first tested the null model in which no predictors were entered. Then, model testing was performed in four steps. In the first step, we introduced the manager (level 1) and the supervisor (level 2) control variables along with the variables used to measure managers' use of hard and soft influence tactics. In the second step, influence tactic ambidexterity was added to the model. In the third step political skill (the moderator) was added and finally, in step four we entered the interaction term (political skill $\mathrm{x}$ influence tactic ambidexterity). Table 2 summarizes HLM results.

*** Insert Table 2 about here ***

The null model is analogous to an analysis of variance in that it partitions the variance into within- and between-group components, rendering it a necessary step before testing full models (Hofmann, Griffin, \& Gavin, 2000). The estimate of the variance residing between groups is the intraclass correlation coefficient (ICC[1]). For subordinates' task performance, the ICC[1] indicated that $16 \%$ of the variance in subordinates' task performance resided between groups, indicating that HLM is suited for analyzing the data.

In step 1 of the HLM analysis, we introduced the manager-level (level 1) and supervisor-level (level 2) control variables. From the control variables, only organizational tenure $(\gamma=.02, p<.10)$ was marginally significantly related to managers' task performance.

Hypothesis 1, states that influence tactic ambidexterity will have a positive impact on task performance. To test this hypothesis, we added to the model the influence tactic ambidexterity variable in step 2 . Supporting hypothesis 1 , influence tactic ambidexterity was positively and significantly related to managers' task performance $(\gamma=.10, p<.05)$. Of interest is the finding that the sole use of hard or soft tactics is not related to managers' task performance.

Hypothesis 3, posits that political skill will positively moderate the effect of influence tactic ambidexterity on task performance. To examine this hypothesis, we first entered the 
moderating variable (political skill) in step 3 and then, in step 4, we entered the interaction term between influence tactic ambidexterity and political skill. The results revealed that political skill positively and significantly moderates the aforementioned relationship $(\gamma=.07$, $p<.05$ ). Consistent with hypothesis 3, Figure 1 demonstrates that when there is a high degree of political skill, the relationship between influence tactic ambidexterity and task performance is stronger. To further explore the form of this significant interaction, we examined the aforementioned relationship at two levels of political skill (one standard deviation above and one standard deviation below the mean; Aiken \& West, 1991). We also computed the simple slopes at each of these levels (Preacher, Curran, \& Bauer, 2006). The slope representing the high level of political skill was statistically significant $(\gamma=.14, \mathrm{z}=2.93, \mathrm{p}<.01)$, while the low political skill slope failed to reach significance $(\gamma=.07, \mathrm{z}-=1.2, \mathrm{p}=.23)$. This indicates that the positive relationship between influence tactic ambidexterity and task performance is statistically significant only for managers with high levels of political skill, providing further support to hypothesis 3.

*** Insert Figure 1 about here $* * *$

\section{Coefficient of Variance Analysis}

Hypothesis 2 posits that the group consisting of managers who exhibit influence tactic ambidexterity will be subject to less intragroup variation in their task performance than the groups consisting of managers that mostly rely on the use of either hard or soft tactics. To examine the groups' task performance variation, we divided the sample into four groups based on the median cut-off criterion: (1) no emphasis, (2) soft tactics, (3) hard tactics, and (4) influence tactic ambidexterity group. In this analysis, the influence tactic ambidexterity group consisted of respondents that reported a high use of both hard and soft tactics; the soft tactics group, was high on soft, but low on hard influence tactics; the hard tactics group, high on hard and low on soft influence tactics and the no emphasis group consisted of the 
remaining respondents that reported a low use of both hard and soft tactics.

Then, to test this hypothesis, we first performed a test of homogeneity of variance (Levene test) to assess whether groups exhibit equal variances and hence comparison among groups is meaningful. The Levene test of equality of variances was significant (Levene statistic $=4.35, \mathrm{p}<.01$ ), indicating that variances among groups differ. To assess the variation in task performance for each of the four groups of managers, we computed the coefficient of variance, which is also known as relative standard deviation, by dividing the standard deviation by the mean for each group (Harrison \& Klein, 2007; He \& Wong, 2004). The results from the coefficient of variance analysis presented in Table 3 shows that managers who rely most on hard tactics (i.e., hard tactics group) demonstrated the highest coefficient of variance (17.67), followed by the soft tactics (14.06) and the no-emphasis group (13.78). Interestingly, although soft and hard tactics groups had a very similar mean value in terms of task performance, those who rely on soft tactics exhibit less intragroup variation in their task performance. The influence tactic ambidexterity group scored the lowest ratio (8.16), supporting our hypothesis that those managers who display influence tactic ambidexterity exhibit more stable task performance. Compared to the ambidextrous group, the no-emphasis group had a similar mean value in task performance, which was not, however, equally stable. Finally, the analysis shows that those who use less frequently hard or soft influence tactics (i.e., no emphasis group) manage to receive higher and more stable task performance evaluations compared to the group of managers who rely mostly on soft or hard tactics.

$$
\text { *** Insert Table } 3 \text { about here **** }
$$

\section{Discussion}

Ambidexterity has received burgeoning interest in the literature. Most studies have focused their attention on the organizational level, examining factors that can drive and leverage the ability of an organization to achieve ambidexterity and through it enhance organizational 
performance (for a review see Raisch \& Birkinshaw, 2008). Realizing that ambidexterity can occur at different levels within the organization, parallel to these studies, other research has shifted its attention to the unit (e.g., Chang, 2015; Kostopoulos et al., 2015) and team level (e.g., Jansen, Kostopoulos, Mihalache, \& Papalexandris, in press; Kostopoulos \& Bozionelos, 2011), while researchers have also examined the pivotal role that top managers can play in achieving organizational ambidexterity (e.g., Lubatkin, Simsek, Ling, \& Veiga, 2006; Mihalache, Jansen, Van den Bosch, \& Volberda, 2014). Furthermore, an important stream of research has concentrated on the contextual role of HRM in enhancing exploration and exploitation capabilities and learning in organizations (e.g., Huang \& Kim, 2013; Kang \& Snell, 2009).

Further expanding extant research on ambidexterity, this study responds to recent calls for research on ambidexterity from a micro-foundational lens and specifically on the constructive and disruptive roles of power and politics in social relationships (Ahammad et al., 2015; Junni et al., 2015) by investigating the role of influence dynamics and political skill on task performance. To shed more light on the efficacy of managers to get their job done, we first examined whether the joint use of two antipodal influence tactics (hard and soft), which we coined influence tactic ambidexterity, can increase their task performance as assessed by their supervisors. Also, we examined whether such higher performance is subject to less variation compared to the sole use of hard or soft tactics. We tackled these issues by showing that managers need to display multiple and competing behaviors that have the capacity to both control as well as inspire others depending on organizational demands (Havermans et al., 2015). We also argued that managers’ political skill may act as a moderator to the influence tactics ambidexterity-performance relationship. To ground this hypothesis, we reasoned on the potency of political skill to mask managers' motives, communicate and network effectively with others, and behave in genuine ways that do not threaten relational ties. 
Our findings suggest that the group of managers who use both influence tactic categories to a high degree is subject to less variation in their task performance than the group of managers that relies on a single influence style (i.e., hard or soft). Taking research one step further, we observed that influence tactic ambidexterity is positively related to a manager's task performance. Such findings suggest that hard influence tactics, when coupled with soft, can delineate the bounds and designate the underlying conditions and principles of behavior for a fertile relationship between the agent and the target. At the same time, soft influence tactics, when combined with hard influence, contribute to developing and maintaining a quality relationship with targets, avoiding the pitfalls of inertia and social loafing. Moreover, our findings support our theoretical contention that managers’ political skill positively moderates the relationship between influence tactic ambidexterity and the realization of task objectives. At high levels of political skill, the positive relationship between influence tactic ambidexterity and task performance becomes stronger. Overall, our study represents one of the few efforts to systematically develop and test the effects of using antipodal influence tactics. The findings of the present study provide important theoretical and practical implications, which are discussed below.

\section{Theoretical Implications}

Our study contributes to the ambidexterity and international HRM literature in several ways. First, we introduce the concept of influence tactic ambidexterity and explore its performance implications for managers. Ambidexterity has mainly been used in the management literature to denote the use of seemingly incompatible strategies (Simsek, 2009). Here, we apply the notion of ambidexterity to highlight the usefulness of frequently using two adverse influence styles. By developing the concept that hard and soft tactics are complimentary rather than contradictory, we attempt to account for the fact that prior research on influence tactics has provided inconclusive and to some extent conflicting results (Falbe \& Yukl, 1992; Yukl \& 
Chavez, 2002). In general, combinations are more effective than the use of a single influence tactic, depending on the potency of each tactic category. Nonetheless, the use of both hard and soft influence tactics has been criticized due to their seemingly incompatible nature (Case et al., 1988; Mnookin et al., 1996; Yukl \& Chavez, 2002). Our findings, suggest that influence tactic ambidexterity has a positive relationship with task performance and also exhibits less variation than the use of either hard or soft tactics alone. By theoretically integrating adverse influence behaviors, we elevate the importance and the interdisciplinary role of ambidexterity and provide avenues for future research in different scientific fields and levels of analysis.

Second, we provide new insights into the diffusion of ambidexterity downwardly (Birkinshaw \& Gupta, 2013; Havermans et al., 2015) by concentrating on managers’ influence tactic ambidexterity. The changing needs and diverse contexts that many multinational corporations face forward the inherent tensions and paradoxes to managers who are often required to fit into different roles, conflate contrasting ideas, and navigate on uneven terrain. Although literature has acknowledged the necessity to probe more profoundly into the role of individuals to operationalize ambidexterity (Good \& Michel, 2013), research is still scarce (Burgess et al., 2015). This study contributes to this end by highlighting that high performance managers display ambidextrous behaviors when interacting with others. Such paradoxical behavioral manifestation, especially when coupled with political skill, may help managers achieve their tasks and hence move one step closer to building an ambidextrous organization. Therefore, this study may provide an explanatory mechanism about the individual level behaviors that managers in multinational corporations employ to achieve the assigned organizational goals.

Third, we probe the effect of two polar influence processes on the variation of task related outcomes. Despite the traditional interest on the nature and consequences of different types of influence behavior (e.g., Van Knippenberg \& Steensma, 2003), very few studies have 
differentiated between higher-order constructs of influence tactics, based on their relative position in the strength dimension (e.g., Sparrowe et al., 2006; Van Knippenberg et al., 1999a). Specifically, by examining the variation that soft and hard influence tactics exhibit on task performance we aim to broaden our understanding of the effectiveness of specific influence tactics. The exertion of soft tactics is more socially desirable, which could explain their frequent use in motivating targets to carry out specific requests or initiate creative dialogues to resolve conflicts (Ahammad et al., 2015). Still, soft tactics can lead to various dysfunctional outcomes (e.g., social loafing), which may render the use of hard tactics indispensable. Hard tactics produced a greater variation in task performance, which may be attributed to their mode of employment and the target's perceptions of their underlying rationale. Even though hard tactics have been associated with negative outcomes, such as increased resistance and low commitment (Falbe \& Yukl, 1992), their importance should not be diminished. When the use of coercive power is coupled with soft tactics, it could become a powerful means of switching between conflicting modes (e.g., exploration to exploitation roles and vice versa) while easing out the tensions created from this process.

Fourth, we shed light on the moderating role of political skill. By examining its interaction with influence tactic ambidexterity, we highlight the enhancive role of political skill in administering these complementary methods of influence. It has been argued in the literature that politically skilled individuals tactically select the most appropriate methods of influence for particular situations and then show proficiency in the execution of these influence attempts (Kolodinsky et al., 2007; Treadway et al., 2013). In this context, our research has found that political skill can strengthen the efficacy of influence tactic ambidexterity. Hence, our findings can contribute to the overall understanding of job performance, particularly within a social influence context. 
Finally, this study could add insights related to the role of culture in achieving task performance through influence tactic ambidexterity. Specifically, our research relied on data from Greece, which represents a context with different characteristics to US and Anglo-Saxon contexts where most studies in ambidexterity are conducted. Drawing from the cross-national findings of Hofstede, Hofstede, and Minkov (1991) and House, Hanges, Javidan, Dorfman, and Gupta (2004), Greek employees exhibit higher scores in uncertainty avoidance (similarly to Russia, Portugal, and Japan) and power distance (similar to Brazil, Mexico, and the Arab countries). This suggests that employees search for cues related to which tasks to perform and how, while they are more accepting of hierarchy and social inequality (i.e., relatively higher score in power distance dimension) (Hofstede et al., 1991). This shows that the use of hard tactics should not be seen with disdain. On the contrary, we suggest that hard tactics may be needed, or even expected, to provide the necessary sensemaking cues that help others cope with ambiguity in their environment. Greek culture is also collectivistic (similarly to China and many African countries). This implies that employees have a high need to develop and maintain quality relationships with others. Thus, soft tactics could help nurture a supportive and trusting environment. Therefore, in such cultural contexts, the need for ambidextrous behavior from managers may be more pivotal in achieving higher and more stable performance. This may highlight the role of context in such studies and could explain why other studies have found inconclusive or differing effects related to the combined use of hard and soft influence tactics at work (e.g., Yukl \& Chavez, 2002).

\section{Practical Implications for Managers and HRM}

A direct practical implication of this research is that effective managers need to display ambidexterity in their use of influence tactics in order to perform well. Managers that only use hard tactics to achieve performance can attain compliance, but at the same time they may undermine long-term cooperation. In contrast, managers that rely on soft tactics mold a more 
stable environment that favors sanctioned exchanges, nevertheless, reliance on soft tactics may be viewed as a weakness that may lead to functional myopia. Practitioners, however, should also be aware that excessive or misuse of influence tactics can stigmatize one's behavior as non-sanctioned or self-serving (Buchanan, 2008). Furthermore, our findings indicate that ambidextrous managers can exhibit stable results in terms of task performance. Even though managers are generally reluctant to use hard tactics, mainly due to their unpredictable consequences, specific contexts (e.g., high environmental dynamism, crisis situations, and negative perceptions of organizational politics) or individual differences (e.g., quality of the dyadic relationship) may render hard tactics indispensable. In this respect, a managerial style that relies on the use of both influence tactics can be a critical factor for achieving personal and organizational objectives. Therefore, managers may embrace the Aristotelian value of phronesis -also known as prudence or practical wisdom- and start taking prudent decisions that intuitively analyze the different facets of ambiguous situations, proactively evaluate the adequacy of their social capital as well as the consequences of actions and risks in order to employ tactics that are situationally appropriate (Kapoutsis, 2016; Shotter \& Tsoukas, 2014). In turn, HR specialists of ambidextrous organizations need to turn their attention to how they can select and adequately compensate managers that possess phronesis and also try to develop this critical managerial asset through adequate training and hence help build an ambidextrous organization.

Our study has important managerial implications for HRM in multinational corporations. The finding of a positive relationship between influence tactic ambidexterity and managers' task performance further suggests that multinational corporations should design and develop high-commitment HRM practices (McClean \& Collins, 2011) oriented towards enhancing the development of ambidextrous managers (e.g., Medcof \& Song, 2013; Prieto-Pastor \& Martin-Perez, 2015; Prieto \& Pilar Pérez Santana, 2012). An example is 
developing a compensation system and giving incentives in order to generate ambidextrous employees (Yoon \& Chae, 2012). Such motivation-enhancing HRM practices are likely to make managers feel the positive sense of stretch, which is a necessary prerequisite for generating ambidexterity in organizations (Ahammad et al., 2015). Also, the selection and retention of managers with the ability to deal with paradoxical situations is also vital in order to enhance organizational ambidexterity (Junni et al., 2015). Overall, what seems to be needed in multinational corporations is the development of an HR system encompassing HR practices promoting managers’ influence tactic ambidexterity.

Finally, it should be noted that when influence tactic ambidexterity is coupled with political skill, managers' performance can be further enhanced. Having the political skill can contribute towards making the use of these antipodal influence styles seen as authentic, justifiable and consistent. Ambidextrous managers with high levels of political skill can grasp their targets’ interests and be adept in employing situational diagnosis to select the appropriate influence strategy that will lead in effective interactions with them. This finding suggests that HR managers should pay particular attention to the recruitment and selection practices to hire employees with high levels of political skill. Moreover, multinational corporations should expand their training focus to involve programs aimed at developing employees’ political skill. The relevant literature suggests that developing the political skill of employees who are at an early stage of their career has a positive impact on their long term career success (Kimura, 2015). Towards this end, commonly used HR practices and tactics to develop political skill involve role playing exercises, drama-based training, mentoring, developmental simulations (Harris, Kacmar, Zivnuska, \& Shaw, 2007; Kimura, 2015). Even poetry may contribute towards this end as it helps develop critical interpretation, enhance social ties and self-contemplation (Xing \& Liu, 2015). 


\section{Limitations and Future Research}

Various caveats, which provide meaningful directions for future research, should be noted.

First, our study was cross-sectional in nature. Researchers should be cautious when interpreting the results, particularly in what relates to causal relationships between the variables examined. Future studies might employ other longitudinal or experimental designs in order to affirm causality. Future research could also apply experimental designs (e.g., business simulation games), whereby independent observers would extend control for all remaining variables beyond the scope of interest (Yin, 2008) and rate the use and appropriateness of influence attempts in effectively accomplishing particular tasks. Incident studies may be used to assess whether hard and soft tactics should be used simultaneously or whether hard tactics should be used when soft tactics have failed.

Second, the present study does not examine the target of the manager's influence attempt. Therefore, it is not possible to discern whether different influence tactics are more appropriate for different targets (e.g., subordinates, supervisors, peers, customers, suppliers). In this respect, the research methodologies proposed above could also examine dyadic relationships to determine whether the choice of influence tactics is differentiated among different targets and whether it is affected by the target's behavior and performance.

Third, this study concentrated on two disparate influence tactic categories, namely hard and soft. Each of these categories was represented by two influence tactics. Whilst these tactics were selected for being antipodal and representative of the two categories, there are several other tactics that merit consideration, such as coalition building and exchange of favors, which do not neatly fall into the hard or soft influence tactic categories. Future research could also examine how different combinations of these tactics can affect managers' performance and contrast their findings with the results derived from this study. 
Finally, future research could replicate and extend the findings of the present study in different business settings and contexts, which would subsequently increase the validity and the credibility of the findings (Hochwarter, Ferris, \& Hanes, 2011). Furthermore, future studies could investigate the moderating effects that the inner organizational context (e.g., organizational justice, politics perceptions) can have on the influence attempts-outcomes relationship. For example, a negative political environment may expose self-interested influence attempts, thus increasing conflicts and distrust (Kolodinsky et al., 2007). This could have a significant effect on both tactic selection and tactic efficacy.

\section{Conclusion}

The role of individuals in organizational learning and performance has long been acknowledged in the literature (Gibson \& Birkinshaw, 2004; Mom, Van Den Bosch, \& Volberda, 2009). Research in the HRM field goes further to suggest that apart from the inherent value to organizations from individuals' knowledge, skills and abilities, the behavior of individuals also plays an important role in organizational ambidexterity and performance (Kang, Morris, \& Snell, 2007). Given the role of managers’ influence tactic ambidexterity and political skill on task performance depicted in this study, it is imperative that HR practices contribute in promoting a supportive context for ambidextrous and politically skilled individuals. HR practices, which have been found in earlier studies to also contribute to flexibility, alignment and adaptability (Ketkar \& Sett, 2009; Medcof \& Song, 2013), should also be directed at selecting, valuing, creating and promoting managers that can display influence tactic ambidexterity and also possess the political skill to know under which circumstances they should display such behavior. 


\section{References}

Ahammad, M. F., Lee, S. M., Malul, M., \& Shoham, A. (2015). Behavioural ambidexterity The impact of financial incentives on employee motivation, productivity and performance of commercial bank. Human Resource Management, 54(S1), s45-s62.

Ahammad, M. F., Tarba, S. Y., Liu, Y., Glaister, K. W., \& Cooper, C. L. (2016). Exploring the factors influencing the negotiation process in cross-border M\&A. International Business Review, 25(2), 445-457.

Aiken, L., \& West, S. (1991). Multiple regression: Testing and interpreting interactions. Newbury Park, CA: Sage.

Anderson, J. C., \& Gerbing, D. W. (1988). Structural equation modeling in practice: A review and recommended two-step approach. Psychological bulletin, 103(3), 411-423.

Andriopoulos, C., \& Lewis, M. W. (2009). Exploitation-exploration tensions and organizational ambidexterity: Managing paradoxes of innovation. Organization Science, 20(4), 696-717.

Baron, R. A., Lux, S., Adams, G. L., \& Lamont, B. T. (2012). Organizational Politics in Strategic Management and Entrepreneurship. In G. R. Ferris \& D. C. Treadway (Eds.), Politics in Organizations: Theory and Research Considerations (pp. 377-410). New York: Routledge/Taylor \& Francis.

Barry, B., \& Shapiro, D. L. (1992). Influence tactics in combination: The interactive effects of soft versus hard tactics and rational exchange. Journal of Applied Social Psychology, 22(18), 1429-1441.

Berson, Y., \& Sosik, J. J. (2007). The Relationship Between Self Other Rating Agreement and Influence Tactics and Organizational Processes. Group Organization Management, 32(6), 675-698. 
Bing, M. N., Davison, H. K., Minor, I., Novicevic, M. M., \& Frink, D. D. (2011). The prediction of task and contextual performance by political skill: A meta-analysis and moderator test. Journal of Vocational Behavior, 79(2), 563-577.

Birkinshaw, J., \& Gupta, K. (2013). Clarifying the distinctive contribution of ambidexterity to the field of organization studies. Academy of Management Perspectives, 27(4), 287298.

Birtch, T. A., Chiangb, F. T., \& Van Esch, E. (in press). A social exchange theory framework for understanding the job characteristics-job outcomes relationship: the mediating role of psychological contract fulfillment. International Journal of Human Resource Management.

Blake, R. R., \& Mouton, J. S. (1964). The Managerial Grid. Houston: Gulf Publishing.

Brislin, R. W., Lonner, W. J., \& Thorndike, R. M. (1973). Cross-cultural research methods. New York, NY: John Wiley.

Bruins, J. (1999). Social power and influence tactics: A theoretical introduction. Journal of social issues, 55(1), 7-14.

Buchanan, D. A. (2008). You Stab My Back, I'll Stab Yours: Management Experience and Perceptions of Organization Political Behaviour. British Journal of Management, 19(1), 49-64.

Burgess, N., Strauss, K., Currie, G., \& Wood, G. (2015). Organizational Ambidexterity and the Hybrid Middle Manager: The Case of Patient Safety in UK Hospitals. Human Resource Management, 54(S1), s87-s109.

Cao, Q., Gedajlovic, E., \& Zhan, H. (2009). Unpacking organizational ambidexterity: Dimensions, contingencies, and synergistic effects. Organization Science, 20(4), 781796. 
Case, T., Dosier, L., Murkison, G., \& Keys, B. (1988). How managers influence superiors: A study of upward influence tactics. Leadership \& Organization Development Journal, 9(4), 25-31.

Cegarra-Navarro, J. G., \& Dewhurst, F. (2007). Linking organizational learning and customer capital through an ambidexterity context: an empirical investigation in SMEs 1. The International Journal of Human Resource Management, 18(10), 1720-1735.

Chang, S. J., van Witteloostuijn, A., \& Eden, L. (2010). From the editors: Common method variance in international business research. Journal of International Business Studies, 41(178-184).

Chang, Y. Y. (2015). A multilevel examination of high-performance work systems and unitlevel organisational ambidexterity. Human Resource Management Journal, 25(1), 79101.

De Cremer, D., \& Van Hiel, A. (2010). 'Becoming Angry When Another is Treated Fairly’: On Understanding When Own and Other's Fair Treatment Influences Negative Reactions. British Journal of Management, 21(2), 280-298.

Dirks, K. T., \& Ferrin, D. L. (2002). Trust in leadership: Meta-analytic findings and implications for research and practice. Journal of Applied Psychology, 87(4), 611-628.

Dixon, S. E., Meyer, K. E., \& Day, M. (2007). Exploitation and exploration learning and the development of organizational capabilities: A cross-case analysis of the Russian oil industry. Human Relations, 60(10), 1493-1523.

Dosier, L., Case, T., \& Keys, B. (1988). How managers influence subordinates: An empirical study of downward influence tactics. Leadership \& Organization Development Journal, 9(5), 22-31.

Enders, C. K., \& Tofighi, D. (2007). Centering predictor variables in cross-sectional multilevel models: a new look at an old issue. Psychological methods, 12(2), 121-138. 
Epitropaki, O., Kapoutsis, I., Ellen, B. P., Ferris, G. R., Drivas, K., \& Ntotsi, A. (in press). Navigating uneven terrain: The roles of political skill and LMX differentiation in prediction of work relationship quality and work outcomes. Journal of Organizational Behavior.

Falbe, C. M., \& Yukl, G. (1992). Consequences for Managers of Using Single Influence Tactics and Combinations of Tactics. Academy of Management Journal, 35(3), 638652.

Fang, R., Chi, L., Chen, M., \& Baron, R. A. (2015). Bringing political skill into social networks: Findings from a field study of entrepreneurs. Journal of Management Studies, 52(2), 175-212.

Farmer, S. M., \& Maslyn, J. M. (1999). Why Are Styles of Upward Influence Neglected? Making the Case for a Configurational Approach to Influences. Journal of Management, 25(5), 653-682.

Ferris, G. R., Perrewé, P. L., Daniels, S. R., Lawong, D., \& Holmes, J. J. (in press). Social Influence and Politics in Organizational Research What We Know and What We Need to Know. Journal of Leadership \& Organizational Studies.

Ferris, G. R., Treadway, D. C., Brouer, R. L., \& Munyon, T. P. (2012). Political skill in the organizational sciences. In G. R. Ferris \& D. C. Treadway (Eds.), Politics in Organizations: Theory and Research Implications (pp. 487-528). New York: Routledge/Taylor \& Francis.

Ferris, G. R., Treadway, D. C., Kolodinsky, R. W., Hochwarter, W. A., Kacmar, C. J., Douglas, C., \& Frink, D. D. (2005). Development and Validation of the Political Skill Inventory. Journal of Management, 31(1), 126-152.

Ferris, G. R., Treadway, D. C., Perrewé, P. L., Brouer, R. L., Douglas, C., \& Lux, S. (2007). Political Skill in Organizations. Journal of Management, 33(3), 290-320. 
Fisher, R., Ury, W. L., \& Patton, B. (2011). Getting to yes: Negotiating agreement without giving in. New York, USA: Penguin.

Gibson, C., \& Birkinshaw, J. (2004). The antecedents, consequences, and mediating role of organizational ambidexterity. Academy of Management Journal, 47, 209-226.

Good, D., \& Michel, E. J. (2013). Individual Ambidexterity: exploring and exploiting in dynamic contexts. The Journal of psychology, 147(5), 435-453.

Harris, J. N., Maher, L. P., \& Ferris, G. R. (2016). The roles of political skill and political will in job performance prediction: a moderated nonlinear perspective. In E. Vigoda-Gadot \& A. Drory (Eds.), Handbook of Organizational Politics: Looking Back and to the Future (pp. 15-39). Cheltenham, UK: Elgar Publishing.

Harris, K., Kacmar, M., Zivnuska, S., \& Shaw, J. (2007). The Impact of Political Skill on Impression Management Effectiveness. Journal of Applied Psychology, 92(1), 278285.

Harrison, D., \& Klein, K. (2007). What's the difference? Diversity constructs as separation, variety, or disparity in organizations. Academy of Management Review, 32(4), 11991228.

Hart, S. L., \& Quinn, R. E. (1993). Roles executives play: CEOs, behavioral complexity, and firm performance. Human Relations, 46(5), 543-574.

Havermans, L. A., Den Hartog, D. N., Keegan, A., \& Uhl-Bien, M. (2015). Exploring the role of leadership in enabling contextual ambidexterity. Human Resource Management, 54(S1), s179-s200.

He, Z.-L., \& Wong, P.-K. (2004). Exploration vs. Exploitation: An Empirical Test of the Ambidexterity Hypothesis. [Article]. Organization Science, 15, 481-494. 
Heavey, C., Simsek, Z., \& Fox, B. C. (2015). Ambidexterity in SBUs: TMT Behavioral Integration and Environmental Dynamism. Human Resource Management, 54(S1), s223-s238.

Higgins, C. A., Judge, T. A., \& Ferris, G. R. (2003). Influence tactics and work outcomes: a meta-analysis. Journal of Organizational Behavior, 24(1), 89-106.

Hochwarter, W. A., Ferris, G. R., \& Hanes, T. J. (2011). Multi-Study Packages in Organizational Science Research. Building Methodological Bridges (Research Methodology in Strategy and Management, Volume 6), Emerald Group Publishing Limited, 6, 163-199.

Hofmann, D. A., Griffin, M. A., \& Gavin, M. B. (2000). The application of hierarchical linear modeling to organizational research.

Hofstede, G., Hofstede, G. J., \& Minkov, M. (1991). Cultures and organizations: Software of the mind (Vol. 2). New York, USA: McGraw Hill.

Hooijberg, R., Hunt, J., \& Dodge, G. (1997). Leadership complexity and development of the leaderplex model. Journal of Management, 23(3), 375.

House, R. J., Hanges, P. J., Javidan, M., Dorfman, P. W., \& Gupta, V. (2004). Culture, leadership, and organizations: The GLOBE study of 62 societies: Sage publications.

Huang, J., \& Kim, H. J. (2013). Conceptualizing structural ambidexterity into the innovation of human resource management architecture: The case of LG Electronics. The International Journal of Human Resource Management, 24(5), 922-943.

Jansen, J. J., George, G., Van den Bosch, F. A., \& Volberda, H. W. (2008). Senior team attributes and organizational ambidexterity: The moderating role of transformational leadership. Journal of Management Studies, 45(5), 982-1007. 
Jansen, J. J., Kostopoulos, K. C., Mihalache, O. R., \& Papalexandris, A. (in press). A SocioPsychological Perspective on Team Ambidexterity: The Contingency Role of Supportive Leadership Behaviours. Journal of Management Studies.

Jansen, J. J. P., Van den Bosch, F., \& Volberda, H. W. (2006). Exploratory innovation, exploitative innovation and performance: Effects of organizational antecedents and environmental moderators. Management Science, 52(11), 1661-1674.

Jasmand, C., Blazevic, V., \& de Ruyter, K. (2012). Generating sales while providing service: A study of customer service representatives’ ambidextrous behavior. Journal of Marketing, 76(1), 20-37.

Jonason, P. K., Slomski, S., \& Partyka, J. (2012). The Dark Triad at work: How toxic employees get their way. Personality and Individual Differences, 52(3), 449-453.

Jöreskog, K. G., \& Sörbom, D. (1996). LISREL 8: User's reference guide: Scientific Software International.

Junni, P., Sarala, R., Taras, V., \& Tarba, S. (2013). Organizational ambidexterity and performance: A meta-analysis. Academy of Management Perspectives, 27, 299-312.

Junni, P., Sarala, R. M., Tarba, S., Liu, Y., \& Cooper, C. (2015). The role of human resource and organizational factors in ambidexterity. Human Resource Management, S54(s1s28).

Kang, S.-C., Morris, S. S., \& Snell, S. A. (2007). Relational archetypes, organizational learning, and value creation: extending the human resource architecture. Academy of Management Review, 32(1), 236-256.

Kang, S. C., \& Snell, S. A. (2009). Intellectual capital architectures and ambidextrous learning: a framework for human resource management. Journal of Management Studies, 46(1), 65-92. 
Kapoutsis, I. (2016). Playing the political game at work: The roles of politics will, political prudence, and political skill. In E. Vigoda-Gadot \& A. Drory (Eds.), Handbook of Organizational Politics (Vol. 2). Cheltenham, UK: Edward Elgar.

Kapoutsis, I., Papalexandris, A., Nikolopoulos, A., Hochwarter, W. A., \& Ferris, G. R. (2011). Politics perceptions as moderator of the political skill - job performance relationship: A two-study, cross-national, constructive replication. Journal of Vocational Behavior, 78(1), 123-135.

Ketkar, S., \& Sett, P. (2009). HR flexibility and firm performance: Analysis of a multi-level causal model. The International Journal of Human Resource Management, 20(5), 1009-1038.

Kimura, T. (2015). A review of political skill: Current research trend and directions for future research. International Journal of Management Reviews, 17(3), 312-332.

Kipnis, D., \& Schmidt, S. M. (1988). Upward-Influence Styles: Relationship with Performance Evaluations, Salary, and Stress. Administrative Science Quarterly, 33(4), 528-542.

Kipnis, D., Schmidt, S. M., \& Wilkinson, I. (1980). Intraorganizational influence tactics: Explorations in getting one's way. Journal of Applied Psychology, 65(4), 440-452.

Kirkman, B. L., \& Shapiro, D. L. (1997). The impact of cultural values on employee resistance to teams: Toward a model of globalized self-managing work team effectiveness. Academy of Management Review, 730-757.

Kolodinsky, R. W., Treadway, D. C., \& Ferris, G. R. (2007). Political skill and influence effectiveness: Testing portions of an expanded Ferris and Judge (1991) model. Human Relations, 60(12), 1747-1777. 
Kostopoulos, K. C., \& Bozionelos, N. (2011). Team exploratory and exploitative learning: Psychological safety, task conflict, and team performance. Group \& Organization Management, 36(3), 385-415.

Kostopoulos, K. C., Bozionelos, N., \& Syrigos, E. (2015). Ambidexterity and Unit Performance: Intellectual Capital Antecedents and Cross-Level Moderating Effects of Human Resource Practices. Human Resource Management, 54(S1), s111-s132.

Lawrence, K., Lenk, P., \& Quinn, R. (2009). Behavioral complexity in leadership: The psychometric properties of a new instrument to measure behavioral repertoire. The Leadership Quarterly, 20(2), 87-102.

Lewis, M. (2000). Exploring paradox: Toward a more comprehensive guide. Academy of Management Review, 25(4), 760-776.

Lewis, M., \& Dehler, G. (2000). Learning through Paradox: A Pedagogical Strategy for Exploring Contradictions and Complexity. Journal of Management Education, 24(6), 708-725.

Liden, R. C., \& Mitchell, T. R. (1988). Ingratiatory Behaviors in Organizational Settings. The Academy of Management Review, 13(4), 572-587.

Lubatkin, M. H., Simsek, Z., Ling, Y., \& Veiga, J. F. (2006). Ambidexterity and performance in small-to medium-sized firms: The pivotal role of top management team behavioral integration. Journal of Management, 32(5), 646-672.

Lvina, E., Johns, G., \& Vandenberghe, C. (in press). Team political skill composition as a determinant of team cohesiveness and performance. Journal of Management.

McClean, E., \& Collins, C. J. (2011). High-commitment HR practices, employee effort, and firm performance: Investigating the effects of HR practices across employee groups within professional services firms. Human Resource Management, 50(3), 341-363. 
Medcof, J. W., \& Song, L. J. (2013). Exploration, exploitation and human resource management practices in cooperative and entrepreneurial HR configurations. The International Journal of Human Resource Management, 24(15), 2911-2926.

Meglio, O., King, D. R., \& Risberg, A. (2015). Improving Acquisition Outcomes with Contextual Ambidexterity. Human Resource Management, 54(S1), s29-s43.

Mihalache, O. R., Jansen, J. J., Van den Bosch, F. A., \& Volberda, H. W. (2014). Top management team shared leadership and organizational ambidexterity: A moderated mediation framework. Strategic Entrepreneurship Journal, 8(2), 128-148.

Mintzberg, H. (1983). Power in and around organizations. Englewood Cliffs, NJ: PrenticeHall.

Mnookin, R. H., Peppet, S. R., \& Tulumello, A. S. (1996). The Tension Between Empathy and Assertiveness. Negotiation Journal, 12(3), 217-230.

Mom, T. J. M., Van Den Bosch, F. A. J., \& Volberda, H. W. (2007). Investigating managers’ exploration and exploitation activities: The influence of top-down, bottom-up, and horizontal knowledge inflows. Journal of Management Studies, 44(6), 910-931.

Mom, T. J. M., Van Den Bosch, F. A. J., \& Volberda, H. W. (2009). Understanding variation in managers' ambidexterity: Investigating direct and interaction effects of formal structural and personal coordination mechanisms. Organization Science, 20(4), 812828.

Munyon, T. P., Summers, J. K., Thompson, K. M., \& Ferris, G. R. (2015). Political skill and work outcomes: A theoretical extension, meta-analytic investigation, and agenda for the future. Personnel Psychology, 68(1), 143-184.

O'Reilly, C. A., \& Tushman, M. L. (2013). Organizational ambidexterity: Past, present, and future. The Academy of Management Perspectives, 27(4), 324-338. 
Patel, P. C., Messersmith, J. G., \& Lepak, D. P. (2013). Walking the tightrope: An assessment of the relationship between high-performance work systems and organizational ambidexterity. Academy of Management Journal, 56(5), 1420-1442.

Perrewé, P. L., Zellars, K. L., Ferris, G. R., Rossi, A. M., Kacmar, C. J., \& Ralston, D. A. (2004). Neutralizing job stressors: Political skill as an antidote to the dysfunctional consequences of role conflict stressors. Academy of Management Journal, 47, 141152.

Pfeffer, J. (1981). Power in organizations. Boston: Pitman.

Preacher, K. J., Curran, P. J., \& Bauer, D. J. (2006). Computational tools for probing interactions in multiple linear regression, multilevel modeling, and latent curve analysis. Journal of educational and behavioral statistics, 31(4), 437-448.

Prieto-Pastor, I., \& Martin-Perez, V. (2015). Does HRM generate ambidextrous employees for ambidextrous learning? The moderating role of management support. The International Journal of Human Resource Management, 26(5), 589-615.

Prieto, I. M., \& Pilar Pérez Santana, M. (2012). Building ambidexterity: The role of human resource practices in the performance of firms from Spain. Human Resource Management, 51(2), 189-211.

Rafferty, A. E., \& Restubog, S. L. D. (2011). The Influence of Abusive Supervisors on Followers' Organizational Citizenship Behaviours: The Hidden Costs of Abusive Supervision. British Journal of Management, 22(2), 270-285.

Raisch, S., \& Birkinshaw, J. (2008). Organizational ambidexterity: Antecedents, outcomes, and moderators. Journal of Management, 34(3), 375-409.

Raudenbush, S., Bryk, A., Cheong, Y., \& Congdon, R. (2004). Hierarchical Linear and Nonlinear Modeling. Scientific Software International. Inc., Lincolnwood. 
Raudenbush, S. W., \& Bryk, A. S. (2002). Hierarchical linear models: Applications and data analysis methods (Vol. 1): Sage.

Schriesheim, C. A., \& Hinkin, T. R. (1990). Influence tactics used by subordinates: A theoretical and empirical analysis and refinement of the Kipnis, Schmidt, and Wilkinson subscales. Journal of Applied Psychology, 75(3), 246-257.

Shotter, J., \& Tsoukas, H. (2014). In search of phronesis: Leadership and the art of judgment. Academy of Management Learning \& Education, 13(2), 224-243.

Simsek, Z. (2009). Organizational Ambidexterity: Towards a Multilevel Understanding. Journal of Management Studies, 46(4), 597-624.

Smith, W. K., \& Tushman, M. L. (2005). Managing strategic contradictions: A top management model for managing innovation streams. Organization Science, 16(5), 522-536.

Sparrowe, R. T., Soetjipto, B. W., \& Kraimer, M. L. (2006). Do leaders' influence tactics relate to members' helping behavior? It depends on the quality of the relationship. Academy of Management Journal, 49, 1194-1208.

Stokes, P., Moore, N., Moss, D., Mathews, M., Smith, S. M., \& Liu, Y. (2015). The MicroDynamics of Intraorganizational and Individual Behavior and Their Role in Organizational Ambidexterity Boundaries. Human Resource Management, 54(S1), s63-s86.

Tepper, B. J., Brown, S. J., \& Hunt, M. D. (1993). Strength of Subordinates' Upward Influence Tactics and Gender Congruency Effects. Journal of Applied Social Psychology, 23(22), 1903-1919.

Treadway, D. C., Breland, J. W., Williams, L. M., Cho, J., Yang, J., \& Ferris, G. R. (2013). Social Influence and Interpersonal Power in Organizations: Roles of Performance and Political Skill in Two Studies. Journal of Management, 39(6), 1529-1553. 
Turner, N., \& Lee-Kelley, L. (2012). Unpacking the theory on ambidexterity: An illustrative case on the managerial architectures, mechanisms and dynamics. Management Learning, 44(2), 179-196.

Turner, N., Swart, J., \& Maylor, H. (2013). Mechanisms for managing ambidexterity: a review and research agenda. International Journal of Management Reviews, 15(3), 317-332.

Tushman, M. L., \& O’Reilly III, C. A. (1996). The Ambidextrous Organizations: Managing evolutionary and revolutionary change. California Management Review, 38(4), 8-28.

Tyler, T. R., \& Blader, S. L. (2003). The Group Engagement Model: Procedural Justice, Social Identity, and Cooperative Behavior. Personality and Social Psychology Review, 7(4), 349-361.

Van de Vliert, E., Nauta, A., Giebels, E., \& Janssen, O. (1999). Constructive conflict at work. Journal of Organizational Behavior, 20(4), 475-491.

Van Knippenberg, B., \& Steensma, H. (2003). Future Interaction Expectation and the Use of Soft and Hard Influence Tactics. Applied Psychology: An International Review, 52(1), $55-67$.

Van Knippenberg, B., Van Eijbergen, R., \& Wilke, H. (1999a). The Use of Hard and Soft Influence Tactics in Cooperative Task Groups. Group Processes Intergroup Relations, 2(3), 231-244.

Van Knippenberg, B., Van Knippenberg, D., Blaauw, E., \& Vermunt, R. (1999b). Relational Considerations in the Use of Influence Tactics. Journal of Applied Social Psychology, 29(4), 806-819.

Wang, C. L., \& Rafiq, M. (2014). Ambidextrous Organizational Culture, Contextual Ambidexterity and New Product Innovation: A Comparative Study of UK and Chinese High-tech Firms. British Journal of Management, 25(1), 58-76. 
Wihler, A., Frieder, R., Blickle, G., Oerder, K., \& Schütte, N. (2016). Political skill, leadership and performance: the role of vision identification and articulation. In E. Vigoda-Gadot \& A. Drory (Eds.), Handbook of Organizational Politics: Looking Back and to the Future (pp. 59-94). Cheltenham, UK: Edward Elgar.

Williams, L. J., \& Anderson, S. E. (1991). Job satisfaction and organizational commitment as predictors of organizational citizenship and in-role behaviors. Journal of Management, 17(3), 601-617.

Xing, Y., \& Liu, Y. (2015). Poetry and leadership in light of ambiguity and logic of appropriateness. Management and Organization Review, 11(4), 763-793.

Xing, Y., Liu, Y., Tarba, S., \& Wood, G. (in press). A cultural inquiry into ambidexterity in supervisor-subordinate relationship. The International Journal of Human Resource Management.

Yin, R. (2008). Case study research: Design and methods. Thousand Oaks, CA: Sage.

Yoon, S. J., \& Chae, Y. J. (2012). Management of paradox: a comparative study of managerial practices in Korean and Japanese firms. The International Journal of Human Resource Management, 23(17), 3501-3521.

Yukl, G., \& Chavez, C. (2002). Influence tactics and leader effectiveness. In L. Neider \& C. A. Schriesheim (Eds.), Leadership: Research in management (Vol. 2, pp. 139-165). Greenwich: Information Age Publishing.

Yukl, G., Seifert, C. F., \& Chavez, C. (2008). Validation of the extended Influence Behavior Questionnaire. The Leadership Quarterly, 19(5), 609-621. 
Table 1. Means, standard deviations, and correlations

\begin{tabular}{|c|c|c|c|c|c|c|c|c|c|c|c|}
\hline Level 1 Variables & $\mathbf{N}$ & Mean & s.d. & 1 & 2 & 3 & 4 & 5 & 6 & 7 & 8 \\
\hline 1. Hard influence tactics & 172 & 3.06 & 1.15 & - & & & & & & & \\
\hline 2. Soft influence tactics & 172 & 4.78 & 1.05 & $.33^{* *}$ & - & & & & & & \\
\hline 3. Influence tactic ambidexterity & 172 & 0.40 & 1.58 & -.04 & $-.52^{* *}$ & - & & & & & \\
\hline 4. Political skill & 172 & 5.34 & .69 & $.22^{* *}$ & $.30^{* *}$ & -.13 & - & & & & \\
\hline 5. Gender & 172 & 1.47 & .50 & -.09 & -.08 & -.10 & -.14 & - & & & \\
\hline 6. Age & 172 & 37.80 & 7.65 & .06 & -.07 & $.21^{* *}$ & .06 & $-.30^{* *}$ & - & & \\
\hline 7. Organizational tenure & 172 & 7.00 & 6.00 & .01 & $.01^{*}$ & 0.03 & .03 & $-.16^{*}$ & $.57^{* *}$ & - & \\
\hline 8. Task performance $^{\dagger}$ & 172 & 5.81 & 0.78 & .03 & -.01 & .19 & -.03 & .01 & -.05 & -.02 & - \\
\hline \multicolumn{12}{|l|}{ Level 2 Variables } \\
\hline 1. Gender & 68 & 1.34 & 0.48 & - & & & & & & & \\
\hline 2. Age & 68 & 42.93 & 6.94 & -.12 & - & & & & & & \\
\hline 3. Organizational tenure & 68 & 10.69 & 7.08 & -.01 & $.58^{* *}$ & - & & & & & \\
\hline $\begin{array}{l}{ }^{*} \mathrm{p}<.05,{ }^{* *} \mathrm{p}<.01 \\
\dagger \text { Supervisor rated }\end{array}$ & & & & & & & & & & & \\
\hline
\end{tabular}


Table 2. Results of HLM analyses predicting manager' task performance

Task Performance

\begin{tabular}{|c|c|c|c|c|}
\hline \multirow[b]{2}{*}{ Independent variable } & \multirow[b]{2}{*}{ Step 1} & \multirow[b]{2}{*}{ Step 2} & \multirow[b]{2}{*}{ Step 3} & \multirow[b]{2}{*}{ Step 4} \\
\hline & & & & \\
\hline Intercept & $5.79 * * *$ & $5.79 * *$ & $5.79 * *$ & $5.79 * *$ \\
\hline Supervisor's Gender & -.05 & -.05 & -.05 & -.05 \\
\hline Supervisor's Age & -.01 & -.00 & -.00 & -.00 \\
\hline Manager’s Organizational Tenure & .02 & .02 & .02 & .02 \\
\hline Manager’s Gender & .08 & .11 & .11 & .10 \\
\hline Manager's Age & -.01 & -.01 & -.01 & -.01 \\
\hline Manager’s Organizational tenure & .02 & .02 & .02 & .02 \\
\hline Hard influence tactics & .02 & .01 & .02 & .01 \\
\hline Soft influence tactics & -.06 & .02 & .04 & .03 \\
\hline Influence tactic ambidexterity & & $.10^{*}$ & $.05 *$ & $.11^{*}$ \\
\hline Political skill & & & -.14 & -.14 \\
\hline Influence Tactic Ambidexterity $\times$ & & & & $.07 *$ \\
\hline \multicolumn{5}{|l|}{ Political Skill } \\
\hline Deviance & 393.74 & 391.42 & 390.01 & 388.59 \\
\hline$\Delta$ Deviance (as $\chi^{2}$ ) & 5.72 (8 df) & 2.32 (1 df) & 1.41 (1 df) & $1.41(1 \mathrm{df})$ \\
\hline
\end{tabular}


Table 3. Coefficient of variance for task performance

\begin{tabular}{lcccc}
\hline Group & $\mathrm{N}$ & Mean & S.D. & Coefficient \\
& & Task & Task & of Variance \\
& & Performance & Performance & (x100) \\
\hline (1) No-emphasis & 47 & 5.95 & 0.75 & 13.78 \\
(2) Soft tactics & 39 & 5.59 & 0.86 & 14.06 \\
(3) Hard tactics & 31 & 5.53 & 0.99 & 17.67 \\
(4) Ambidextrous & 55 & 6.01 & 0.49 & 8.16 \\
\hline
\end{tabular}

Notes

$N=172$. Test of Homogeneity of Variances: Levene statistic $=4.35 \mathrm{p}<$

.01 ; equal variances assumption is rejected. 
Figure 1. Interaction of political skill and influence tactic ambidexterity on managers' task performance.

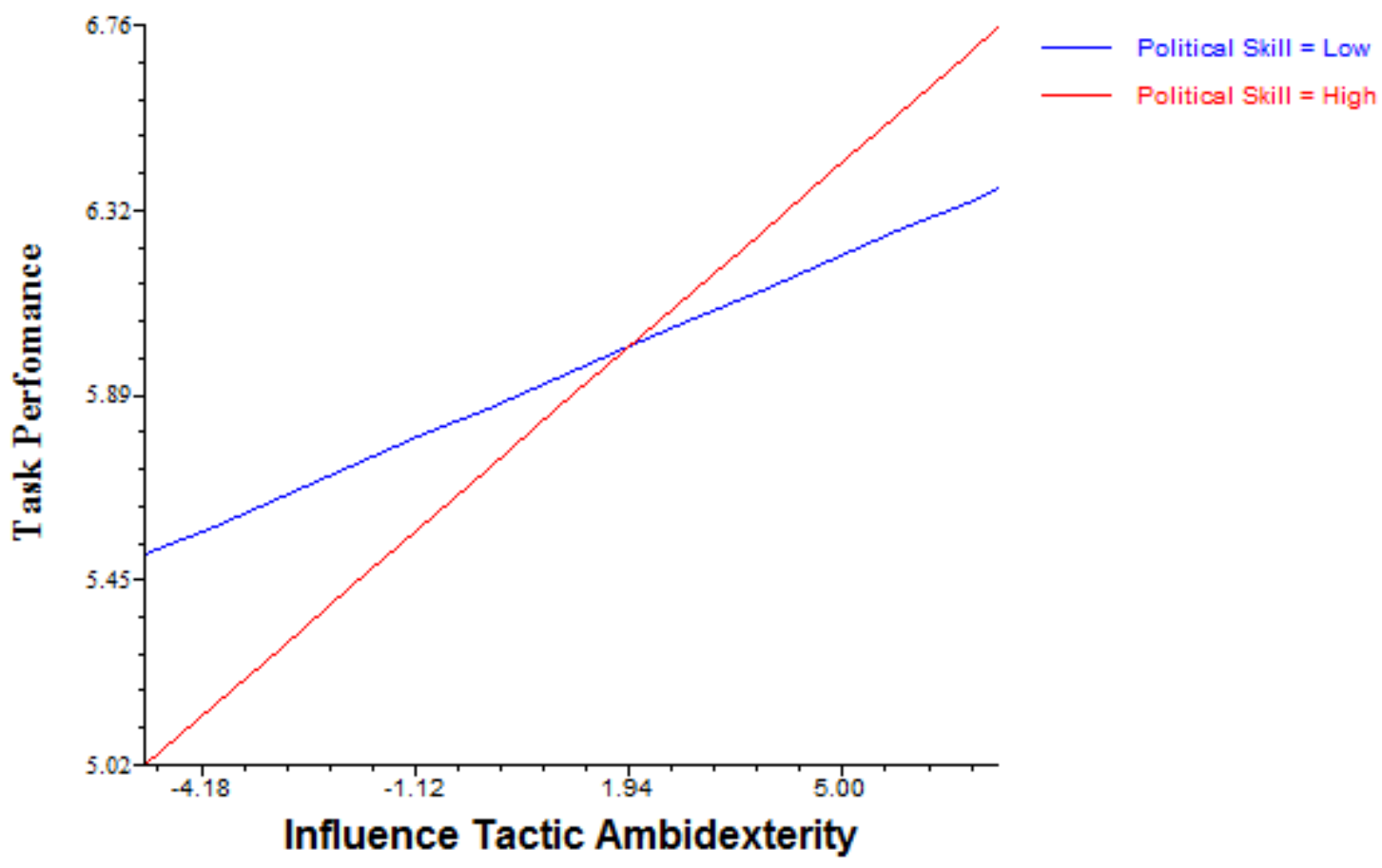

